\title{
Globalization Impact on the Maritime Trade between the USA and the Slovak Republic
}

\author{
Peter Mako ${ }^{1,}$, Andrej David ${ }^{1}$, Andrea Galierikova ${ }^{1 *}$ and Matus Materna ${ }^{2}$ \\ ${ }^{1}$ University of Zilina, Faculty of Operation and Economics of Transport and Communications, \\ Department of Water Transport, Univerzitna 1, 01026 Zilina, Slovakia \\ ${ }^{2}$ University of Zilina, Faculty of Operation and Economics of Transport and Communications, Air \\ Transport Department, Univerzitna 1, 01026 Zilina, Slovakia
}

\begin{abstract}
.
Research background: The paper background is based on the importance of maritime trade. The paper offers a proposal for container transport in two different directions along two different transport routes, taking into consideration all trends in the development of port transhipment facilities as well as the development of container transport. The final comparison is determined based on criteria such as speed and complexity of the transport, distance, price for transportation, as well as the risk of endangering the cargo due to shipping through risky geographical areas. These factors, together with other facts, significantly contribute to the final choice of the shipping route both by the shipper and the carrier.

Purpose of the article: The main purpose of this paper is to present the basic possibilities of container transportation by sea between North America and Europe, to express the importance of the Transatlantic maritime transport route and to offer a comparison of two transport proposals in a case study.The main objective of the paper is to evaluate the impact of globalization on maritime trade between the USA and Europe, especially the Slovak Republic. Given the rapidly evolving maritime transport situation between North America and Europe, special consideration is also given to the current technical equipment and transhipment technology in the ports through which this trade takes place.

Methods: The method used in the paper is the least squares method, that will be used on the prediction of future stage of maritime trade between Slovakia and the USA. For this purpose, methods of regression and correlation analysis will be also used.

Findings \& Value added: According to data from Review of Maritime Transport between $1995-2018$, the prediction of stage of maritime trade will be made. The development of the maritime trade will be also predicted.
\end{abstract}

Keywords: maritime trade; maritime transport, ships; shipping route; correlation; regression

JEL Classification: F60; F69; L91,

\footnotetext{
* Corresponding author: galierikova@,fpedas.uniza.sk
} 


\section{Introduction}

Maritime transport is an important part of global trade. It enables to transport all types of cargo among the continents. A lot changes have appeared in the world since the second half of the 20th century. These changes have led to introduce of new transport units containers. The importance of these units has grown especially in the sector of maritime transport. Simplicity of handling operations of containers in maritime ports and wide range of possibilities in intermodal transport have a positive effect on transport of cargo in the containers in the international seaborne trade. Nowadays, containers are important parts for the commodities which are transported overseas and container terminals are creating traditional parts of many maritime ports in the world. In Europe we can find these ports in Rotterdam, Hamburg, in the United States, there is the Port of Los Angeles or New York and in Asia there are a lot of large ports such as Shanghai, Singapore, Shenzhen. The existence of main shipping routes has a substantial effect on the development of these ports, too. The development of container transportation on these routes has a significant influence on the economy of countries and the future of container transportation among different parts of the world.

\section{Methods}

The importance of each of the transport routes can be assessed from many points of view. One of the most objective is the assessment based on the total amount of goods transported on a given transport route in a certain period. From the point of view of container transport, it is necessary to deal with the statistics of transport of this commodity in order to assess the importance of the given route. The statistics collected on the transport of containers on the Transatlantic Transport Route serve as a basis for estimating future developments on the basis of the least squares method. Using the least squares method, it is possible to find an approximation function based on which. The use of this function consists mainly in the graphical and numerical expression of the future development of transport. If this methodology is used, it is necessary to have as much data as possible on the amount transported in the past. The accuracy of this methodology is significantly limited to a short period of time. Therefore, this article presents an estimate for a maximum of 5 years. Sudden and unforeseeable circumstances cannot be effectively included in this methodology. These unpredictable factors may have an impact in the short term, but are not expected to be more pronounced in the long term. Based on the findings, this paper also provides a case study, where these data are also supported by a comparison of the presented proposals. The comparison is presented based on the two most important factors, namely the price for transport and the total time of transport. As a result of the comparison, this article tries not only to present the possibilities and recommendations of which route the customer can use, but also underlines the results of the estimation of future development obtained on the basis of the least squares method.

\section{Results}

\subsection{Seaborne trade, import and export between Europe and the USA}

Global maritime trade is divided into geographical regions all over the world. Europe and the USA are the most important parts of global maritime trade. So, it is important to know their main centres of maritime trade and main transport routes. 


\subsubsection{European seaborne trade}

Europe is one of the most important regions in the world from the point of view of maritime trade. The international importance of this region comes from the favourable economic conditions and the size of the population, which is constantly expanding. Europe wants to improve these conditions so that European countries could rely on international trade. Maritime transport is a significant part of this trade. Europe has favourable geographical conditions for this type of transport. The sufficient length of the coast, apart from the border with the Russian Federation, gives the European economy the space for efficient functioning of maritime trade. [1]

The west coast provides access to the Atlantic Ocean, in the north there is an access to the Baltic and North Seas, in the south, there is a vast area of the Mediterranean Sea and in the southeast, we can find a direct access to the Black Sea region. These areas of maritime trade in Europe can be divided into the three most important areas - Western Europe, the Baltic Sea and the area around the Mediterranean Sea. [1]

The northwest coast of the European continent is one of the busiest maritime areas in the world. There are major ports of world maritime trade such as Hamburg, Rotterdam, Southampton or Le Havre. The importance of this area is also growing due to its connection to the most important inland waterway - the river Rhine. This area creates a link between European inland river and maritime ports. The connection of inland waterway with the port of Rotterdam is important for international trade. The Rhine also plays an important role in the field of container transportation within the continent. [2]

\subsubsection{North American seaborne trade}

The territory of North America covers an area of Canada and the USA on an area of 1.9 million hectares. This region is one of the most economically developed areas in the world. The most important goods produced in this area include steel, cereals, oil, coal and natural gas. The territory of North America can be ranked among the richest regions in the world with a high level of consumption. The import of cars and containers from East Asia and Europe is growing now, too. We can divide North America into three economically important areas. The first area is situated near Chicago and Pittsburgh. This area has important sources of coal and iron ore. The second area is the large agricultural area in the central part of continent, where mainly agricultural crops are grown. The last area is the mountainous part of the Rocky Mountains, which separate the Pacific Ocean from the rest of the continent. [1]

According to these facts, we can say that the geographical characteristics of the continent and the location of the main waterways have an impact on the direction of imports and exports for different types of cargo. Grain exports, from a belt that stretches across the midwestern United States and the Canadian prairies, are made through seaports on the Gulf Coast or through the Great Lakes system on the U.S.- Canadian border. Coal export from the vicinity of the Appalachian Mountains on the east coast, or from mining areas in Canada, flows mainly through the ports of Norfolk and Hampton roads on the east coast. The other important directions of coal export are the Gulf of Mexico in the south and the port of Vancouver on the west coast of Canada. Timber is exported mainly through ports on the northwest coast, such as Seattle and Vancouver. Oil is exported mainly through ports on the shore of Hudson Bay, the southern coast of Alaska and ports on the Gulf Coast. In the case of container transportation, ports located on the Transatlantic and Transpacific shipping routes have the greatest influence. These ports are Los Angeles, Long Beach and New Jersey. [1] 


\subsection{Import and export between the USA and Europe}

Important indicators of the international trade, which also includes maritime transport, are the state of import and export. Import and export together are the main economic indicators of globalization in international trade. The term export includes the sale of goods or services abroad. Export make a positive contribution to a country's gross domestic product, as well as to the mutual trade balance between countries.

The term import includes the purchase and procurement of goods and services from abroad. In terms of its contribution to the country's gross domestic product as well as its trade balance, it represents the exact opposite of exports and thus has a negative impact on these two types of economic indicators. Prerequisites for the favorable development of these indicators is a need for functioning international trade. [3]

Eurostat [6] claims that the European Union's largest trading partner in terms of exports is the United States. Export from the European Union countries to the USA represents 21\% of the total exports of 28 European Union countries. In 2018, in monetary terms it was worth of 406 billion EUR, while import from the USA to the countries of the European Union in 2018 was worth of 267 billion EUR. From this point of view, it can be stated that the mutual trade balance in 2018 was more favorable for the European Union than for the United States of America. [3]

Trade with products and raw materials predominates in international trade among these important economic units. In 2018, export of cars, machinery and equipment from the European Union to the United States of America accounted for $43 \%$, export of petrochemical products and chemicals was $24 \%$ and export of other types of miscellaneous processed goods was $22 \%$. [3]

On the other hand, Eurostat [3] claims that mainly cars, machinery and equipment accounted for the territory of the Member States of the European Union, accounting for $42 \%$ of total US exports to the European Union, petrochemical products $21 \%$ and other types of products.

Eurostat [3] also reports that, from the perspective of the Member States of the European Union, the United States supplies the most goods to the United Kingdom, Germany and the Netherlands. In monetary terms, import from the United States to the United Kingdom in 2018 amounted to more than 55 billion EUR, to Germany to 48.5 billion EUR and to the Netherlands to more than 39 billion EUR. In terms of export, most products and raw materials are exported to the US from Germany, the United Kingdom and Italy. In 2018, Germany exported more than 114.5 billion EUR worth of goods to the United States, the United Kingdom 54.8 billion EUR and Italy 42.5 billion EUR. According to Eurostat [3], in 2018, import from the United States to the territory of the Slovak Republic amounted to 346 million EUR, which represents $2.2 \%$ of export of goods from the United States to the European Union. From the point of view of export, in 2018 the Slovak Republic exported goods worth 2.6 billion euros to the USA. According to the Ministry of Foreign Affairs of the Slovak Republic [4], more than 600 companies export their products from the territory of the Slovak Republic to the USA. The most common types of products include cars and parts for cars, engineering products, household appliances, electronics and spare parts. [4]

\subsection{Transatlantic shipping route}

In maritime transport there are three main container trade routes on which containers are transported by container vessels. One of these routes is the Transatlantic shipping route that leads through the Atlantic Ocean. The Atlantic Ocean is situated between the most important economic areas of Europe and America. It connects ports on the coast of the Gulf 
of Mexico, the east and west coasts of America with major ports on the North, Baltic, Mediterranean and Black Sea coasts. The main shipping routes leading through the waters of the Atlantic Ocean create the shape of the letter ,S“. The shortest transport routes across the Atlantic Ocean, in the case of container ships, can only be overcome in 5 days. The most common types of transported cargo include the containers of the ISO 1A and ISO $1 \mathrm{C}$ series. [1]

\section{Estimated future development of container transportation}

We can use the smallest squares method to estimate the future development of container transportation between North American and European seaports. This method is based on the conditions where it is not possible to determinate the value of original function with high accuracy. These inaccuracies are mainly caused by different rounding methods or mistakes caused by processes of measuring data. Using the smallest square method, we try to find out an approximation function and it is important that the total sum of obtained squares of the given deviations is as small as possible. [6]

In case of measuring the table values $[(x i, y i), i=0,1,2, \ldots, n]$, which represent the selected measurement values xi and the measured values yi represent the values of the function $f(x)$ at the point $x i$. [6] The result is finding an approximation function in this form:

$$
\varphi(x)=a 0+a 1 x
$$

where: $\varphi(\mathrm{x})$ is the value of the function [pieces, TEU]

$\mathrm{a}_{0}, \mathrm{a}_{1}$ are unknown constants [R]

In this way, we can obtain linear dependence. This dependence is represented by a regression line. Substituting of the measurement number (values from 1 to , $\mathrm{n}^{\prime \prime}$, which in our case represent years of measurement) as unknow $\mathrm{x}$ in the dependence, it is possible to express an estimated future development for next five years. [6]

We can express the most probable development of container transportation for the next 5 years thanks to the approximation function. We can also assume a slight increase in container transportation with a maximum value expected in 2023. This estimate is mainly influenced on the development of transport in the recent period. In the case of the real development of this field over the next five years, some deviations set based on the smallest square method (approximately 0,9 ) can be also expected.

The real development will also be affected by economic conditions, trade agreements signed in the next few years as well as the demand and supply of ship space. 


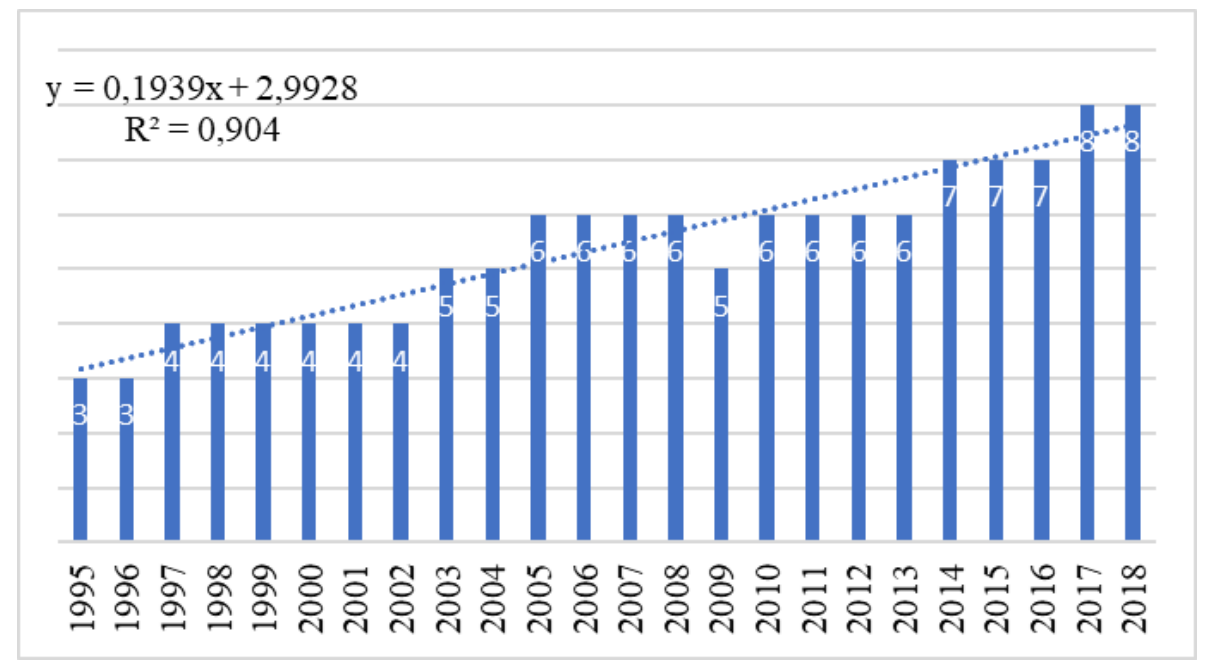

Fig. 1. The development of container transportation between North America and Europe (mil. TEU/year) [7] Authors according to [7]

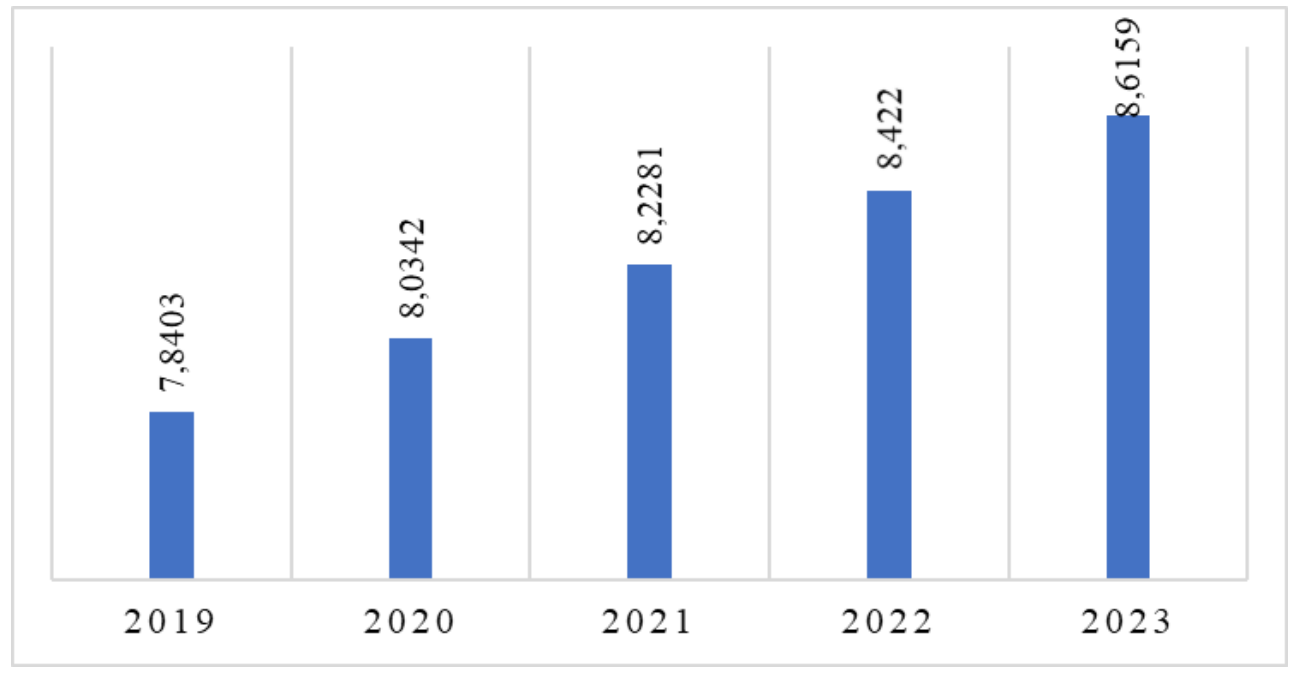

Fig. 1. Estimated future development of container transportation between North America and Europe (mil. TEU/year)

Authors according to [7]

\subsection{Case transport study}

This case study deals with two proposals of container transportation between North America and Europe. It also includes specifications of INCOTERMS delivery clause, import rules related to the USA and description of two different transport routes that can be used. According to information, the final comparison is also added. 


\subsubsection{Incoterms delivery clause}

INCOTERMS delivery clauses, according to DHL [8], are used to determine the requirements of the purchase contract between the seller and the buyer. The rules associated with the application of these clauses determine the liability of the seller and the buyer during the transport of the goods from the place of manufacture to the place of destination. Under the agreed clauses, the seller and the buyer will also clearly agree on the redistribution and transfer of costs and possible risks that may arise during transport. In the case of some clauses, the parties to the purchase contract also have an obligation to provide cargo insurance. Delivery clauses are issued every 10 years. The last update comes from 2020 .

In the case of a specific transport of television cargo from Foxconn's Nitra plant to the Port of Los Angeles, a CIF delivery clause - "cost insurance and freight" - can be considered as an acceptable option. According to the DHL [8], the seller officially fulfills the conditions arising from the purchase by delivering cargo on board the vessel. The obligation of the seller is to pay the costs associated with loading, transport of contractually agreed goods by sea vessel to the place of unloading and costs for unloading cargo, as well as providing export formalities associated with exports. In the case of this delivery clause, the seller is also obliged to insure the goods. The seller is obliged to take out the insurance for a minimum coverage according to ICC C corresponding to $110 \%$ of the value of the cargo. Kuehne-Nagel [9] argues that ICC C insurance covers insurance events related to a fire and explosion on a vessel, shipwreck or stranding of a vessel, sinking and overturning of a vessel, collision of a vessel with another vessel or other obstacle, in the event of a declaration during the voyage, also the unloading of cargo in the port of emergency, the events covered by the general accident and the damage caused by the cargo being dropped overboard.

According to DHL [8], at the time the cargo is placed on board the ship, the potential risk of loss or damage to the goods also passes to the buyer and the seller has fulfilled the obligation to deliver the goods regardless of whether they actually arrive at the destination or arrive at the appropriate destination. condition or quantity. On the other hand, the CIF clause imposes an obligation on the buyer to ensure the formalities for the importation of the goods to the destination, including the additional transport of the goods.

The system of importing goods into the territory of the United States of America is subject to the relevant legislation and conditions of "US Customs and Border Protection". The basic law for importing goods into the United States is the "Tariff Act of 1930". However, many other laws and regulations currently apply that severely restrict imports to the United States. Certain types of products must be subject to special certification. These include food, cars, but also radiation sources and radio transmitters. A specific type of restriction on imports into the US is quotas, which can be applied not only by customs but also by other US government agencies. From the point of view of quotas, it is not only a question of absolute quantification, but also of the application of separate import tariffs to individual products. To protect the US internal market and ensure national security, additional container controls and mandatory importers of goods have been introduced since 2003, as well as mandatory pre-entry reporting. If the goods are re-exported, they can enter separate free trade zones, where it is possible to store or complete them. Such goods are exempt from customs duties and import quotas in the zones concerned. [4] 


\subsubsection{Proposals of container transportation between Europe and North America and their comparison}

There are two main shipping routes that we can use to transport containers between Europe (Slovakia) and North America. The first route from Hamburg to Los Angeles goes through the Atlantic Ocean and the Panama Canal and the second route from Koper leads through the Suez Canal and ports of Shekou and Geelong to the port of Los Angeles. [10]

\subsubsection{Hamburg - Los Angeles}

The first proposal uses standard Transatlantic shipping route. The distance between Hamburg and Los Angeles is 8005 nautical miles. The voyage starts in the port of Hamburg and then leads south-west direction along the Frisian Islands and the coast of Belgium into the English Channel (French: La Manche). After this short part the vessel arrives into the Atlantic Ocean and continues along the Transatlantic shipping route along the Azorean Islands. Next, the container ship crosses the Tropic of Cancer and continues into the Caribbean Sea. The ship continues through the Caribbean Sea and enters into Limón Bay. Limón Bay is the entrance to the Panama Canal. Container vessels cross the Panama Canal through 3 locks and then they continue into the Pacific Ocean. The voyage to Los Angeles leads along the Azuero Peninsula and the Baja California Peninsula. Finally, the container vessel arrives to Los Angeles. [11] [13]

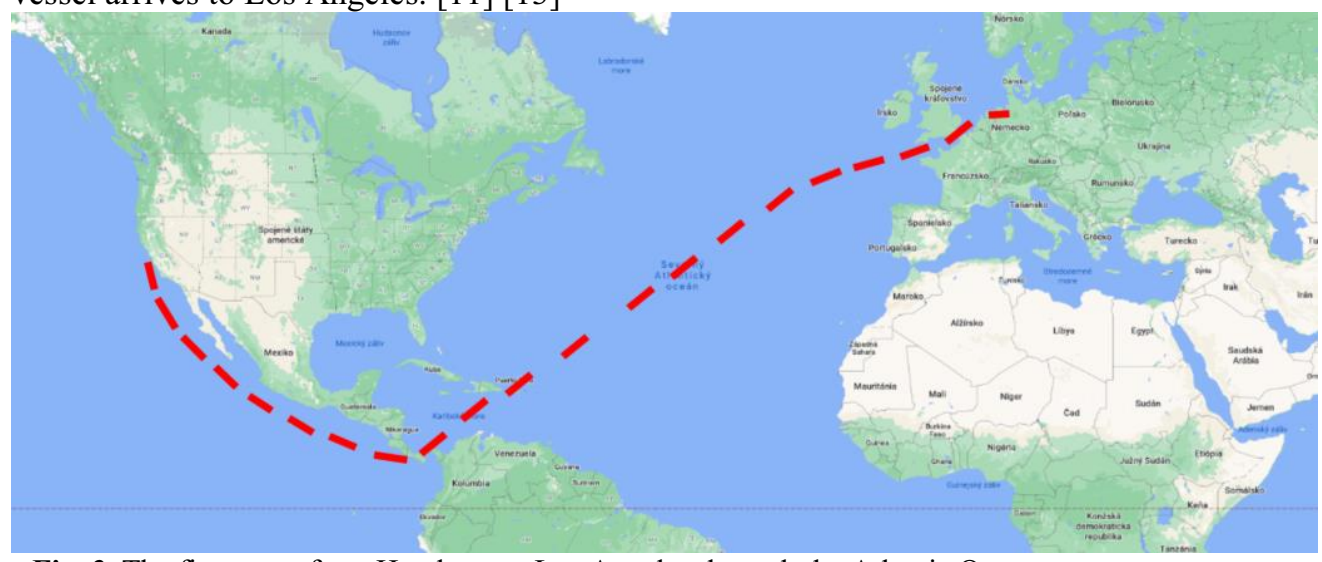

Fig. 3. The first route from Hamburg to Los Angeles through the Atlantic Ocean Authors according to [11]

\subsubsection{Koper - Shekou - Australia - Los Angeles}

The second proposal is an alternative way of container transportation between North America and Europe. The distance between Koper and Los Angeles through China and Australia is about 20000 nautical miles. The voyage starts in Koper, which is the largest port in Slovenia. Container vessels have to sail along the Adriatic coast to get into Ionian Sea through the Strait of Otranto. The main shipping route between the port of Koper and the Suez Canal leads along Corfu, Cephalonia and Zakynthos to the Mediterranean Sea. Then, near the island of Crete the ship is heading to the port of Port Said, which is the main entrance to the Suez Canal. The voyage through the Suez Canal leads through lake Timsah and the port of Ismailia and then through Great Bitter Lake and Little Bitter Lake to the port of Suez. Along the Jazīrat Jūbāl Penisnula and the Ğazīrat Sadwān Peninsula, the ship arrives to the Red Sea. This is the end of the first part of the main shipping route between 
Europe and Asia. The second part starts near Hanīs al Kabīr and the Bab-el-mandeb Strait which connects the Red Sea and the Gulf of Aden. The main shipping route then leads near the island of Socotra and through the Arabian Sea. The container vessel has to change the direction to the Maldives and then to India and Sri Lanka.

After this part, there is a small section near Sumatra, where the ship arrives to the Strait of Malacca between the Malay Peninsula and Sumatra. At the end of this section there is one of the main container ports in the world - the port of Singapore. Vessels which sail from Singapore to the port of Shekou have to cross the Natuna Sea and the South China Sea along the coast of Vietnam. The port of Shekou is the first stop. This port is situated near Macao and belongs to the most important ports in China. $[12,15]$ After this first stop the container vessel continues through the Luzon Strait and through the Philippine Sea to the coast of Papua New Guinea and to the Coral Sea. Then it sails along the coast of Australia to the port of Geelong. After a short stop in the port of Geelong the vessel is ready to sail along the Transpacific shipping route through Tonga, Samoa, Kiribati and the Hawaiian Islands to the port of Los Angeles. [11, 12]

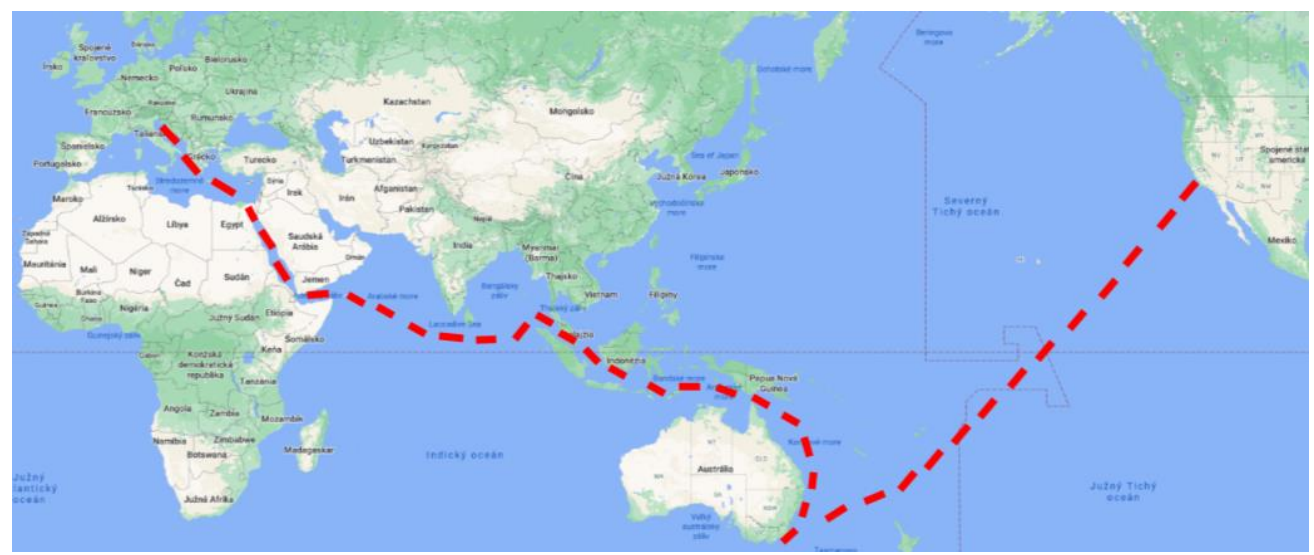

Fig. 2. The second route from Koper through the Suez Canal to the port of Los Angeles Authors according to [11]

\subsubsection{Comparison of proposals}

Speed, reliability and accuracy of delivery are now key requirements of customers. So, the right shipping route plays an important role in this case. From this point of view, the first route has a lot of advantages. The distance between Hamburg and Los Angeles through the Panama Canal is 8005 nautical miles. In the case of ideal sailing and meteorological conditions, the voyage time between the port of Hamburg and the port of Los Angeles through the Panama Canal at the speed of 18 knots would be $19-20$ days. On the other hand, the distance between Koper and Los Angeles through the Suez Canal and ports of Shekou and Geelong is about 20000 nautical miles. So, in the case of ideal conditions and without downtime in ports, sailing on this route at the speed of 18 knots would take approximately 47 days. $[12,14]$. Costs of container transportation are of the significant factors that affect the final price of the product. This factor has an influence on final decisions of customers. [14]

The price for transport is also the factor that influences the choice of carrier and forwarding company. The influence of supply and demand for ship space can be observed as one of the key factors of pricing in maritime transport. In case of maritime transport 
between the port of Hamburg and the port of Los Angeles, the basic tariff rate transportation of all types „FAK “was 2350 USD in January 2020. This tariff rate for transportation of container between the port of Koper and the port of Los Angeles was 2450 USD in February $[10,12,13,15]$. But there are significant differences in the case of additional fees. In the case of shipments between Hamburg and Los Angeles, they totalled 1,116 USD. The resulting preliminary calculation of the price for the transport of an ISO 1 A series container with a gross weight of up to 27 tons by sea is 3,466 USD. In the case of transport of the same type of container and the same gross weight by sea from the port of Koper via Shekou and Geelong to the port of Los Angeles, the additional charges to the basic FAK rate are 578.45 USD and the final price for sea transport is 3028.45 USD. [16, $17,18]$

\section{Conclusion}

The paper deals with description of maritime trade in individual parts of Europe and North America. It emphasizes current and future development of transportation between these geographical parts of the world. According to the estimated future development of container transportation between Europe and North America, we can expect favourable situation in the future.

Based on information about possibilities of transport, taking into account the use of main transport routes, this article offers the possibility of transporting an intermodal transport unit between the place of despatch and the place of delivery. This transportation is designed according to the incoterm's delivery clause CIF.

The final price for transport depends on many factors, such as current state of demand and offer, possibilities of transport, epidemiological situation and business relations between different countries. On the other hand, there are a lot factors that have an influence on final decision of the customer. For example, the time of transport or potential risks and transport companies must not overlook these issues.

These factors and information can provide general view on globalization in seaborne trade.

\section{Discussion}

Based on the previous development of container transport between North America and Europe, it is possible to recognize a growth trend. Upon closer examination of these data and using the least squares method, it is possible to more accurately estimate not only the growth rate itself but, with some deviations, also the quantitative expression of the total amount. An important fact from this point of view, however, is the possibility of unforeseen circumstances that can significantly affect the estimate. However, these circumstances do not necessarily mean an overall change in the established development of the transport of containers on a given transport, but they are likely to manifest themselves only in a certain specific period.

Knowledge of these changes and of future developments will significantly affect the competitive advantage of forwarding companies in submitting proposals to their customers. However, this factor is not the only one that can weigh more significantly when choosing the recommended transport route. Currently, for most customers, one of the most important criteria is the price of transport. This factor largely determines the customer's decision whether or not to accept the offer. An equally significant factor is the transport time.

Customers of transport and forwarding companies are bound by delivery dates. Shorter transport times also mean a faster turnover of finances in mutual business relations between 
the seller and the buyer. In the final comparison, therefore, there is often a discrepancy between price and time of transport. This basic question must therefore be answered on the basis of the customer's overall requirements.

If the customer's preferences are primarily price-oriented and he is willing to accept a longer delivery time, it is more advantageous to offer him a proposal with a lower price but a longer transport time, as is the case with container transport through Koper, Shekou and Geelong. In the case of this route, the price is the biggest advantage. On the other hand, in addition to longer transport times, certain safety risks during navigation must be taken into account. If the customer is willing to accept it due to the lower price, he will certainly consider this offer. It is also advantageous to know the possibility of transport on this route and use it as an alternative option in case of unforeseen circumstances.

In general, however, in the case of transport, solutions that reduce the total time of transporting the cargo are preferred. Such a solution is a proposal to transport containers to Los Angeles via the port of Hamburg. In this case, it is possible to halve the total transit time, compared to the proposal through Shekou and Geelong ports. For this reason, it is possible to observe an increased demand for transport on this route, which is partly reflected in the price for transport. However, according to the data on the development of container transport on the Transatlantic transport route, it can be clearly concluded that this route is chosen by a large number of carriers. Undoubtedly, the safety situation during the voyage is also an advantage. The estimate of future developments presented suggests that the Transatlantic Transport Route will continue to play an important role in transport between Europe and North America in the future.

A comparison and presentation of an estimate of future developments in this article clearly demonstrates the importance of Transatlantic Freight for the transportation of containers between North America and Europe. However, unforeseen circumstances may require the use of an alternative transport route. Therefore, it is necessary to take into account the existence of such routes and one of these routes is presented in the case of the design of transport through the ports of Shekou and Geelong.

Project VEGA No. 1/0128/20: Research on the Economic Efficiency of Variant Transport Modes in the Car Transport in the Slovak Republic with Emphasis on Sustainability and Environmental Impact, Faculty of Operation and Economics of Transport and Communications: University of Zilina, 20202022.

\section{References}

1. Stopford, M. (2009). Maritime Economics 3-rd edition. Oxon: Rutledge, Park Square Abington .

2. Havinga, H. (2020). Towards Sustainable River Management of the Dutch Rhine River. Water, 12(6), 1827.

3. EC.EUROPA. (2020). Globalization in international trade - statistics. Retrieved from: https://ec.europa.eu/eurostat/web/economic-globalisation/globalisation-in-business statistics/international-trade.

4. Department of State (2020). Economic information on the territory of the USA. Retrieved from: https://www.mzv.sk/documents/752200/620840/Spojen\%C3\%A9 $+\% \mathrm{C} 5 \% \mathrm{~A} 1 \mathrm{t} \% \mathrm{C} 3 \% \mathrm{~A} 1$ ty+americk$\% \mathrm{C} 3 \% \mathrm{~A} 9++$ ekonomick $\% \mathrm{C} 3 \% \mathrm{~A} 9+$ inform $\% \mathrm{C} 3 \% \mathrm{~A} 1 \mathrm{cie}+\mathrm{o}+$ terit $\% \mathrm{C} 3 \% \mathrm{~B} 3 \mathrm{riu}+2019$.

5. Wang, W., Shen, W., Tong, T. (2020). Robust estimation of nonparametric function via addition sequence. Journal of Statistical Planning and Inference, 211, 423 - 438. 
6. Parand, K., Aghaei, A.A., Jani, M., Ghodsi, A. (2020). A new approach to the numerical solutions of Fredholm integral equations using least squares-support vector regression. Mathematics and Computers in Simulation, 180, 114-128.

7. Review of Maritime transport. (2019). Retrieved from: https://unctad.org/en/PublicationsLibrary/rmt2019 en.pdf

8. Incoterms 2020. (2020). Retrieved from: https://www.logistics.dhl/sk-sk/home/nase divizie/freight/zakaznicky-servis/incoterms-2020.html

9. Endarti, Ajeng, T. (2012). Variation of Delivery Insurence Coverage in Bogor District 2011. Kesmas-National Public Health Journal.

10. CMA_CGM. (2020). Agent offer. Extenral source.

11. Google maps. (2020). Retrieved from: https://www.google.sk/maps/@13.8624362,122.6856102,3.17z?hl=s

12. Dvorsky, J., Kliestik, T., et al. 2020. The influence of some factors of competitiveness on business risks. Journal Of Business Economics And Management, 21(5), 14511465.

13. Jurkovic, M., Kalina, T., Sosedova, J., Tvrda, E. (2016) Globalization of the LNG trade in Caspian region. In: Globalization and its socio-economic consequences, (793-799). Rajecke Teplice: Conference Proceedings.

14. Dvorak, et. al. (2010) Theoretical background and software support for creation of railway transport model in crisis situations WMSCI 2010. the $14^{\text {th }}$ world multi-conference on systemics, cybernetics and informatics (343-347). Orlando: Conference Proceedings.

15. Tengler, J., et al. (2017). Identification and localization of transport units for selected company. Procedia Engineering, 178, 491-500.

16. Matsuyama, K. (2007). Beyond icebergs: Towards a theory of biased globalization. Review of Economic Studies, 74(1), 253-257.

17. Liu, JG., Wang, JJ. (2019). Carrier alliance incentive analysis and coordination in a maritime transport chain based on service competition. Transportation Research Part E: Logistics and Transportation Rewiew, 128, Pages 333-355.

18. Yuen, KF., Thai, VV., Wong, YD. (2017). Corporate social responsibility and classical competitive strategies of maritime transport firms: A contingency-fit perspective. Transportation Research Part A: Policy and Practice, 98, 1-13. 